\title{
Peroxidase From Peach Fruit: Thermal Stability
}

\author{
Valdir Augusto Neves* and E. J. Lourenço \\ Department of Food Nutrition - Faculty of Pharmaceuticals Sciences - Universidade Paulista Julio de Mesquita \\ Filho - UNESP. Rodovia Araraquara-Jaú Km 1, Araraquara, São Paulo - Brasil.
}

\begin{abstract}
Peroxidase from peach fruit was purified 28.9-fold by DEAE-cellulose, Sephadex G-100 and hydroxylapatite chromatography. The purified enzyme showed only one peak of activity with an optimum $\mathrm{pH}$ of 5.0 and temperature of $40^{\circ} \mathrm{C}$. The calculated activation energy (Ea) for the reaction was $7.97 \mathrm{kcal} / \mathrm{mol}$. The enzyme was heat-labile in the temperature range of 60 to $80^{\circ} \mathrm{C}$ with a fast inactivation at $80^{\circ} \mathrm{C}$. PAGE of the inactivation course at $70^{\circ} \mathrm{C}$ showed only one band of activity. Different sugars increased the heat stability of the activity in the following order: sucrose>lactose> glucose>fructose. Measurement of residual activity showed a stabilizing effect of sucrose at various temperature/sugar concentrations $(10$ to $40 \%, w / w)$ with the Ea for inactivation increasing with sucrose concentration from 0 to $20 \%(\mathrm{w} / \mathrm{w})$. After inactivation at $70^{\circ} \mathrm{C}$ and $75^{\circ} \mathrm{C}$ the enzyme was able to be reactivated by up to $40 \%$ of the initial activity when stored at $30^{\circ} \mathrm{C}$.
\end{abstract}

Keywords: Peach peroxidase, purification, heat stability, regeneration.

\section{INTRODUCTION}

Peroxidases (donor: hydrogen peroxidase oxidoreductase, E.C.1.11.1.7, POD) are widely distributed in the plant kingdom, and have been associated with many metabolic and physiological changes in tissues: e.g, lignin biosynthesis (Abeles \& Biles, 1991), extensin polymerization (Gillikin \& Graham, 1991), auxin metabolism (Haard, 1977), disease resistance (Hammerschmidt et al., 1984; Smith \& Hammerschmidt, 1988), and ripening and senescence of fruits (haard, 1973; Gorin \& Heidema, 1976). The enzyme has been also involved in deteriorative changes in flavor, texture and color in raw and processed fruits and vegetables (Vamos-Vigyàzo, 1981; Burnette, 1977). Peroxidase from plants is an iron-containing enzyme, generally of broad substrate specificity, which occurs in multiple molecular forms and is present in most fruits and vegetables investigated in soluble and bound forms (ionically and covalently bound) whose catalytic properties are influenced by variety or/and cultivar, growth and physiological stages. Changes in peroxidase activity during fruit ripening have been the subject of many studies
(Gorin \& Heidema, 1976; Rhotan \& Nicolas, 1989; Silva et al, 1990; Miesle et al., 1991; Khan \& Robinson, 1993a). Although this class of enzyme has been extensively studied, the physiological function of its individual members is only partially understood. This might be due, in part, to the complexity of the peroxidase isoenzymes present in plant tissues.

Thermal inactivation of peroxidase is perhaps the most important aspect investigated in relation to this enzyme and several works have shown that the effect of heat treatment on the activity was related to the denaturation rate of the protein, and that peroxidase activity appeared to be regenerated depending on conditions of time and heating temperature (Khan \& Robinson, 1993b; Hemeda \& Klein, 1991; Schmidt \& Vamos-Vigiàzo, 1985, Lu \& Whitaker, 1974; Tamura \& Morita, 1975). Sugars and polyhydric alcohols, such as glycerol and sorbitol, can help stabilize biological macromolecules (Lee \& Timashef, 1981; Arakawa \& Timashef, 1982; Neucere \& St Angelo, 1985) preventing the loss of aldheyde dehydrogenase activity (Bradbury \& Jacoby, 1972), stabilizing calf brain microtubule protein (Frigon \& Lee,

\footnotetext{
Author for correspondence
} 
1972) protecting active bovine pancreatic ribonuclease against denaturation by heat, acid and urea (Gerisma, 1968). Sugars have also been utilized as anti-denaturant agents against freeze and heat-induced denaturation of muscle food products (Park \& Lanier, 1987). Although extensive investigations on the behavior of peroxidase during heating and cooling have contributed to a better understanding of the catalytic properties of the enzyme, studies on the effects of solvent additives on the thermal behavior of peroxidase are very limited. To our knowledge the most recent study related to this aspect was published by Chang et al., 1988.

Our laboratory is interested in studying the effect of some additives on the thermal stability of vegetable food enzymes. To this end, in this study we have examined the thermal behavior of soluble peroxidase, the major peroxidase fraction present in the peach fruit cultivar utilized in this investigation. Some enzymatic properties of the enzyme are also presented.

\section{MATERIALS AND METHODS}

Peach fruit (Prunus persica L.), cv. Rei da Conserva, grown under standard conditions in the State of São Paulo were picked at the ripe stage, washed, peeled, cut into small pieces and used for enzyme extraction.

\section{Extraction-purification of peroxidase -} Twenty-five $g$ of peach tissue was homogenized in $0.1 \mathrm{M}$ potassium phosphate buffer, $\mathrm{pH} 6.5$ containing $1 \mathrm{mM}$ l-cystein with Polyclar AT $(0.1 \mathrm{~g} / 10 \mathrm{~g}$ of tissue $)$ as phenolic scavenger. The suspension was centrifuged at $25000 \mathrm{x}$ g for 30 min. The supernatant was collected (crude extract) and dialysed against solid PEG-20000 to concentrate the protein. After concentration to a small volume the extract was applied to a column of DEAE-cellulose $(1.5 \times 20 \mathrm{~cm})$, previously equilibrated and washed with $5 \mathrm{mM}$ phosphate buffer, $\mathrm{pH}$ 7.0. Protein was eluted with a linear gradient of $\mathrm{KCl}(0-0.4 \mathrm{M})$ in $5 \mathrm{mM}$ potassium phosphate buffer, $\mathrm{pH} 7.0$ and $5.5 \mathrm{ml}$ fractions were collected. The active fractions were pooled and applied to a column of Sephadex G-100 ( 2 x $48 \mathrm{~cm})$ equilibrated and washed with the same buffer. The fractions with peroxidase activity were combined, concentrated (solid PEG-20000) and applied to a column of hydroxylapatite $\left(\begin{array}{llll}1 & \mathrm{x} & 10 & \mathrm{~cm}\end{array}\right)$, previously equilibrated with $10 \mathrm{mM}$ phosphate buffer, $\mathrm{pH}$ 7.5. Protein was eluted with a gradient of the same buffer (10 to $200 \mathrm{mM}$ ). All procedures were carried out at $4^{\circ} \mathrm{C}$.

Enzyme assay - Peroxidase activity was determined by the change in absorbance at 460 $\mathrm{nm}$ due to o-dianisidine oxidation in the presence of hydrogen peroxide. The reaction mixture consisted of $0.2 \mathrm{ml} 15 \mathrm{mM}$ odianisidine; $0.2 \mathrm{ml} 10 \mathrm{mM}$ hydrogen peroxide, $0.1 \mathrm{M}$ potassium phosphate-citrate buffer, $\mathrm{pH}$ 5.0 , together with the enzyme in a total volume of $3.0 \mathrm{ml}$. One enzyme unit is defined as the amount of enzyme producing a 0.001 absorbance change per min under the assay conditions used.

Protein determination - Protein concentration was determined by the method of Lowry et al., (1951), using bovine serum albumin as a standard.

Thermal stability - Thermal stability of soluble POD as a function of temperature was determined over the range of 60 to $90^{\circ} \mathrm{C}$ using $0.1 \mathrm{M}$ potassium phosphate-citrate buffer, $\mathrm{pH}$ 7.0. The enzyme solution was placed in a test tube in a water bath, pre-set at the appropriate temperatures. Aliquots of enzyme solution were withdrawn at timed intervals, rapidly cooled in an ice bath and assayed for the remaining activity under the assay conditions described above. Percent residual activity was calculated as percent of the original activity in the unheated preparation. To study the effect of sugars on heat stability, POD was incubated in the presence of sucrose, lactose, fructose or glucose. The apparent activation energy (Ea) for inactivation was determined by measuring the reaction rate constant for inactivation at different temperatures in the presence and absence of sugars.

pH Optimum and pH stability - The optimum $\mathrm{pH}$ for POD activity was determined in potassium phosphate-citrate $(\mathrm{pH} 3.0-6.5)$, and Tris- $\mathrm{HCl}(\mathrm{pH} 7.0-8.0)$ buffers. The stability of the enzyme at different $\mathrm{pH}$ values was studied 
by incubating the samples in the same buffer for $2 \mathrm{~h}$ at $30^{\circ} \mathrm{C}$. POD activity was assayed under standard conditions as described above.

Reactivation study - To determine the reactivation of POD activity, aliquots in triplicate of the enzyme in $10 \mathrm{mM}$ potassium phosphate buffer, $\mathrm{pH}$ 7.0, were placed in test tubes sealed with parafilm and incubated in a water bath. The tubes were held for 3,6 or $12 \mathrm{~h}$ at $30^{\circ} \mathrm{C}$, after heat treatment at $70^{\circ} \mathrm{C}$ and $75^{\circ} \mathrm{C}$ for 1,3 or $10 \mathrm{~min}$. POD activity was measured before treatment and after 3,6 or $12 \mathrm{~h}$ at $30^{\circ} \mathrm{C}$ for total regeneration. POD activity is expressed as percent of original activity in the purified preparation. All enzyme assays were performed in triplicates.

Electrophoresis - Polyacrylamide gel electrophoresis (PAGE) was performed at $\mathrm{pH}$ 8.3 by the method of Davis, 1964 . The gels were stained for activity bands by immersing in $0.2 \%$ (w/v) o-dianisidine in $80 \%$ methanol at $\mathrm{pH} \mathrm{6.0,}$ followed by addition of $30 \mathrm{mM} \mathrm{H} \mathrm{H}_{2} \mathrm{O}_{2}$. Stained bands indicating peroxidase activity appeared within $20 \mathrm{~min}$ at $37^{\circ} \mathrm{C}$ and the gels were rinsed in distilled water.

\section{RESULTS AND DISCUSSION}

\section{Purification of soluble POD}

Typical activity data for the various stages of purification of peach soluble POD are given in Table 1. The results presented here are representative of five separate purification trials, and the elution patterns were highly reproducible. The use of $\left(\mathrm{NH}_{4}\right)_{2} \mathrm{SO}_{4}$ to concentrate the protein extracted resulted a low recovery of POD activity present in the extract. This low recovery ruled out the conventional $\left(\mathrm{NH}_{4}\right)_{2} \mathrm{SO}_{4}$ method for concentrating the enzyme. Among the various concentration methods tried, dialysis of the crude extract against solid polyethylene glycol (PEG-20000) was the most effective with no loss in enzyme activity. The enzyme preparation was applied to a DEAE-cellulose column, however, the peroxidase did not adsorb to the column and was eluted with the wash buffer. The collected enzyme applied to a Sephadex G-100 column, eluted in a single peak and the bulk of $280 \mathrm{~nm}$ absorbing material was eluted after activity peak elution, resulting in a 11.7-fold purification. Peroxidase activity was eluted as a single peak, indicating the presence of either a single enzyme species or more than one species of similar molecular weight. Soluble peroxidase did not adsorb to hydroxylapatite and was eluted with the wash buffer; this step brought about a 28.9fold purification (table I). The fractions with highest peroxidase activity were pooled and used in the assays.

The PAGE patterns of purified peroxidase showed the presence of two peroxidases components which did not vary during the purification procedure (figure 1).

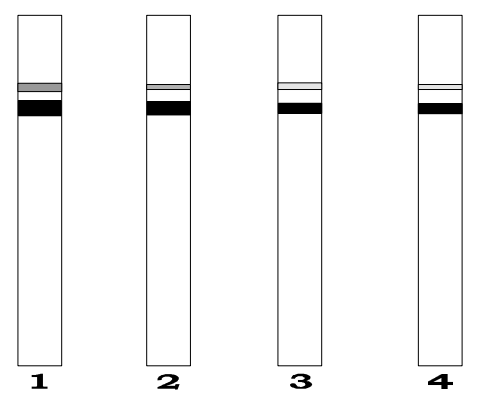

Fig. 1 - Electrophoretic patterns of peroxidase. (1) crude extract, (2) DEAE-cellulose (peak), (3) Sephadex G100 (peak) and (4) hydroxylapatite (peak). Reaction on the gel were estimated accord to described.

The optimum $\mathrm{pH}$ was 5.0 with activity falling off rapidly above and below this value and reaching half of the maximum value at $\mathrm{pH}$ 6.5. This $\mathrm{pH}$ optimum corresponded well to optimum $\mathrm{pH}$ values for peroxidase in green peas (Halpin et al., 1989); soybean (Sessa \& Anderson, 1981); sweet potato (Neves \& Lourenço, 1985) and kiwifruit (Soda et al., 1991). The optimum $\mathrm{pH}$ of peroxidase activity varied with the enzyme source, the isoenzyme composition, the donor substrate and the buffer applied, and for most vegetable sources studied occurred in a range of $\mathrm{pH}$ 4.5-6.5 (VàmosVigyàzo, 1981). The $\mathrm{pH}$ stability study revealed that the enzyme was remarkably stable over the $\mathrm{pH}$ range 3.5-8.0 when held for $2 \mathrm{~h}$ in an ice bath, but when incubated at $30^{\circ} \mathrm{C}$ there was a marked decrease 
Table I - Summary of the steps purification of peroxidase.

\begin{tabular}{lccc}
\hline \multicolumn{1}{c}{ Procedure } & $\begin{array}{c}\text { Total activity } \\
\left(\text { units x } \mathbf{~ 1 0}^{\mathbf{3}}\right)\end{array}$ & $\begin{array}{c}\text { Specific activity } \\
(\text { units/mg protein) }\end{array}$ & $\begin{array}{c}\text { Purification } \\
\text { (factor) }\end{array}$ \\
\hline & & & \\
Crude extract & 507.3 & $39.3 \times 10^{3}$ & 1 \\
DEAE-cellulose & 497.6 & $102.9 \times 10^{3}$ & 2.6 \\
Sephadex G-100 & 301.4 & $458.7 \times 10^{3}$ & 11.7 \\
Hydroxylapatite & 279.4 & $1136.0 \times 10^{3}$ & 28.9 \\
\hline
\end{tabular}

in stability below $\mathrm{pH} 5.0$ and at $\mathrm{pH} 3.0$ the enzyme was completely inactivated. The optimum temperature was found to be $40^{\circ} \mathrm{C}$ and the activation energy (Ea) for the catalytic oxidation of o-dianisidine estimated from an Arrhenius plot at temperature between $15^{\circ} \mathrm{C}$ and $60^{\circ} \mathrm{C}$, was found to be $7.97 \mathrm{kcal} / \mathrm{mol}$. The $\mathrm{Km}$ and Vmax values (Lourenço \& Neves, 1997) indicated that the enzyme presented a higher specificity for o-dianisidine than hydrogen peroxide as described (Soda et al., 1991).

\section{Thermal inactivation}

Data showing the effect of heating time and temperature on enzyme inactivation are presented in Figure 2 (A to D). The results showed that peroxidase was reasonably stable at temperature of $60^{\circ} \mathrm{C}$. Marked inactivation occurred at temperatures above $70^{\circ} \mathrm{C}$, with the enzyme being completely inactivated after $30 \mathrm{~s}$ at $80^{\circ} \mathrm{C}$. Although peroxidase has been recognized to be quite resistant to thermal inactivation, the results presented here showed that soluble POD from peach was less resistant to heating than peroxidase from most vegetable sources. At all temperatures the enzyme was heated in the presence of sucrose at final concentrations of $0,10,20$ and $40 \%$ in the incubation mixture. In the temperature range of 60 to $80^{\circ} \mathrm{C}$, the increase in sucrose concentration corresponded to an increase in enzyme stability. It was also observed that enzyme activity was more resistant to inactivation regardless of the heating temperature and sugar concentration used, by comparison to controls without the sugar (Figure $2 \mathrm{~A}$ to D). Figure $3 \mathrm{~A}$ and B show the effect of different sugars on thermal stability of the enzyme. When POD was heated at 70 and $75^{\circ} \mathrm{C}$ in the presence of sucrose, lactose, glucose or fructose at final concentrations of $10 \%$ in the incubation mixture, a protective effect on enzyme activity was observed. It appeared that sugars increased the heat stability of the enzyme as measured by loss of activity. All the sugars exhibited the protective effect which increased in the order of fructose $<$ glucose < lactose < sucrose and corresponded to the decrease in the reducing power of sugars. The activation energies (Ea) for inactivation of the enzyme in the presence or absence of sucrose were estimated from an Arrhenius plot at temperatures between 60 and $80^{\circ} \mathrm{C}$. The calculated values revealed an increase in Ea in the presence of sucrose. It was also noted that the Ea values increased with sugar concentration: Ea values of $29.6 \mathrm{kcal} / \mathrm{mol}$, $39.6 \mathrm{kcal} / \mathrm{mol}$ and $49.6 \mathrm{kcal} / \mathrm{mol}$ were found at 0,10 and $20 \%$ sucrose, respectively. In a previous study Chang et al., 1988, reported that horseradish peroxidase (HRP) was less susceptible to thermal inactivation when heated in $40 \%$ sucrose solution, but in contrast to the results presented here for peach POD, these investigators showed that $20 \%$ sucrose solution reduced the thermal stability of the horseradish enzyme.

Based on their study on the effect of sucrose, lactose and other additives on thermal stability of rulactine from Micrococcus caseolyticus, Yoovidhya et al.,1986, suggested that the effect of the same additive may differ for the different enzymes.

According to these authors, this might be due to the nature of the enzyme and particularly due to its hydrophilic-hydrophobic balance. In the case of peroxidase, the results presented here and in those reported by Chang et al.1988, indicated that the enzymes from different sources could also behave differently when heated in the presence of sugars. 

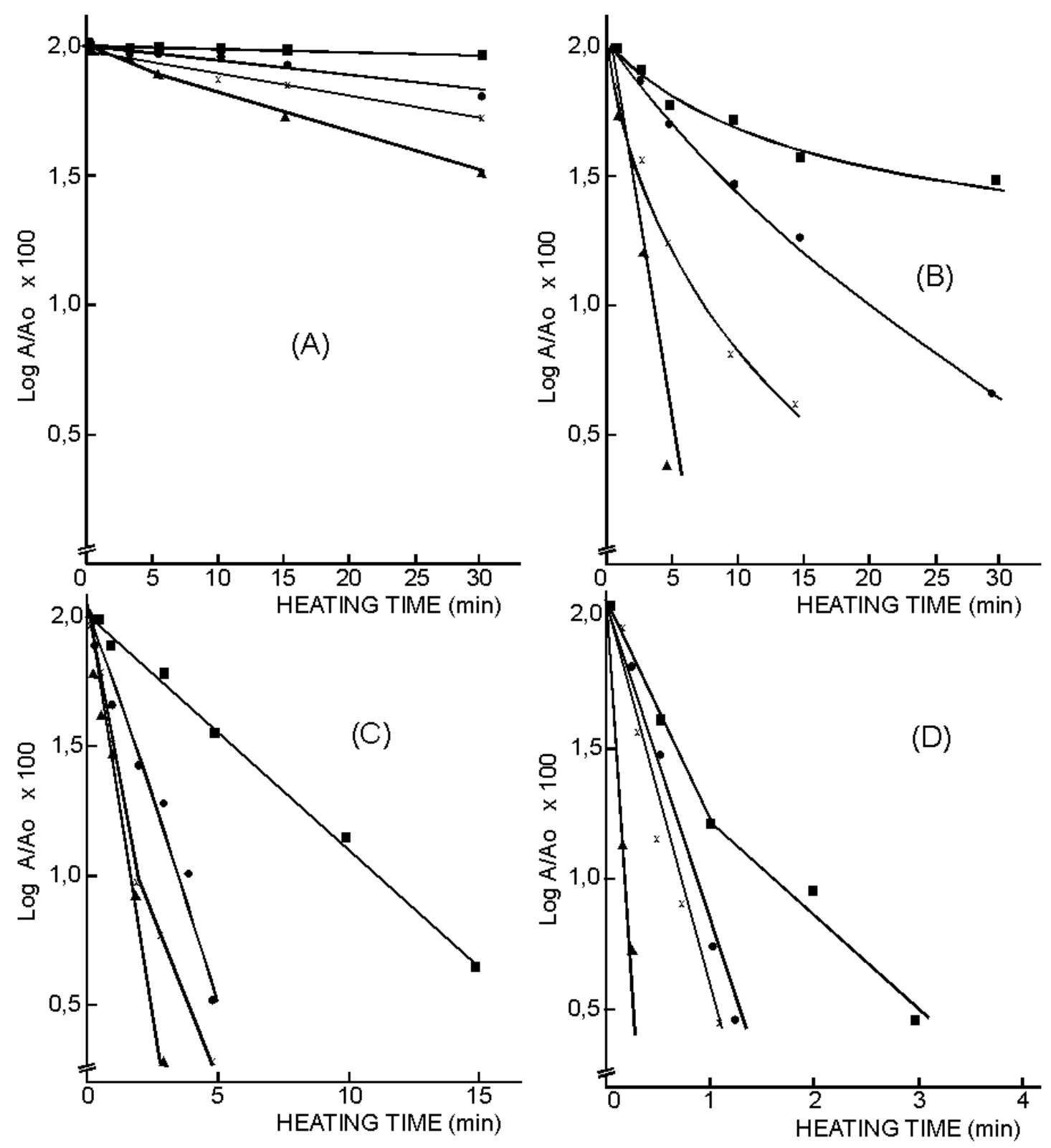

Fig. 2 - Heat inactivation curves of POD in the presence of sucrose $\left(A_{o}\right.$ and $A$, initial and residual activity, respectively). (A) $60^{\circ} \mathrm{C}$, (B) $70^{\circ} \mathrm{C},(\mathrm{C}) 75^{\circ} \mathrm{C}$, (D) $80^{\circ} \mathrm{C}$. (४) no additives, (X) $10 \%,(\bullet) 20 \%$, (•) $40 \%$ sucrose concentration $(\mathrm{w} / \mathrm{w} \%)$.

In order to evaluate the ability of the enzyme to be reactivated after heating, the activity regained following heating at 70 and $75^{\circ} \mathrm{C}$ for 1 , 3 and 10 min was determined (Figure $4 \mathrm{~A}$ and B). After partial inactivation of soluble peroxidase at both temperatures, there was a regain of activity as a function of incubation time at $30^{\circ} \mathrm{C}$. Maximum regeneration of activity occurred within $6 \mathrm{~h}$ after heating and was independent of the extent of inactivation. 

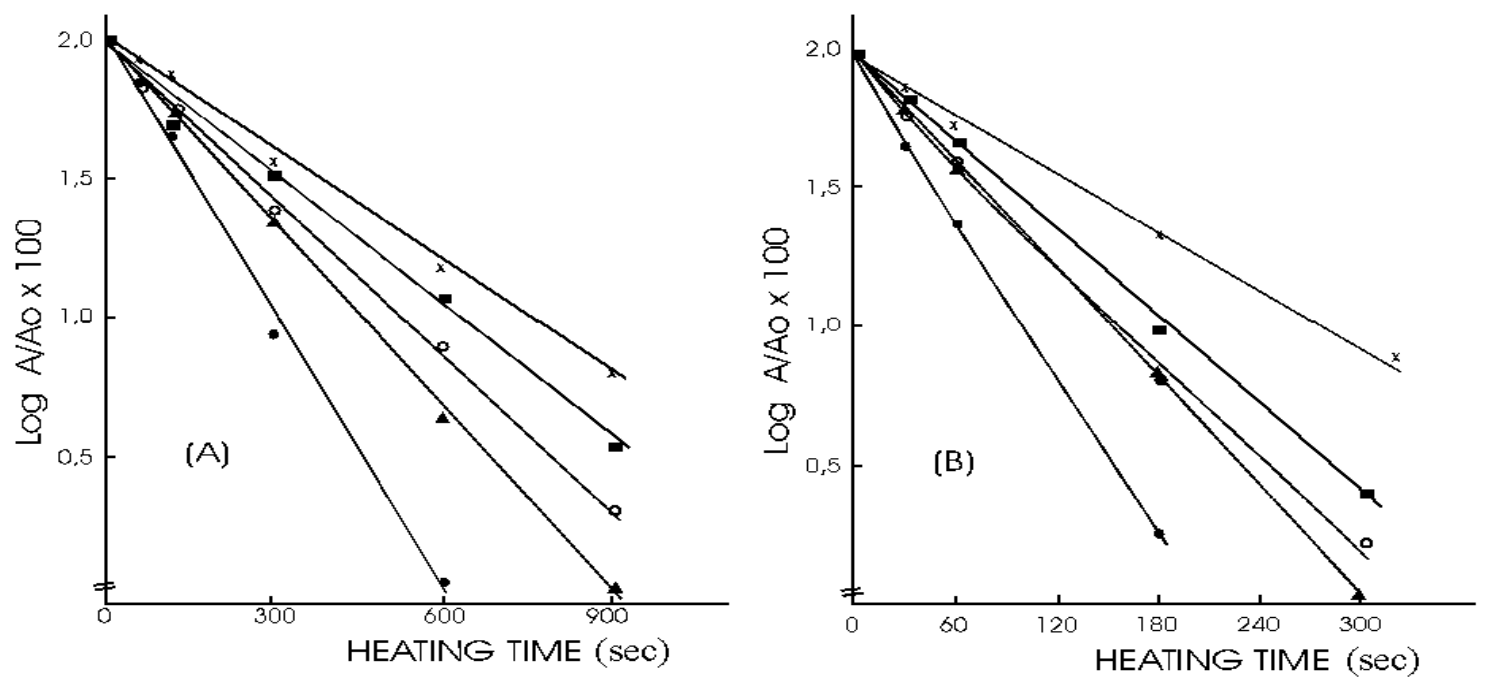

Fig 3 - Heat inactivation curve of POD in the presence of various sugars. $\left(A_{o}\right.$ and $A$; initial and residual activity,

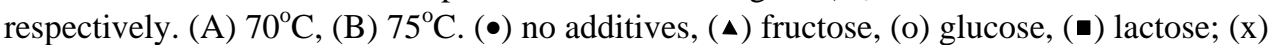
sucrose, all at $10 \%(\mathrm{w} / \mathrm{w})$
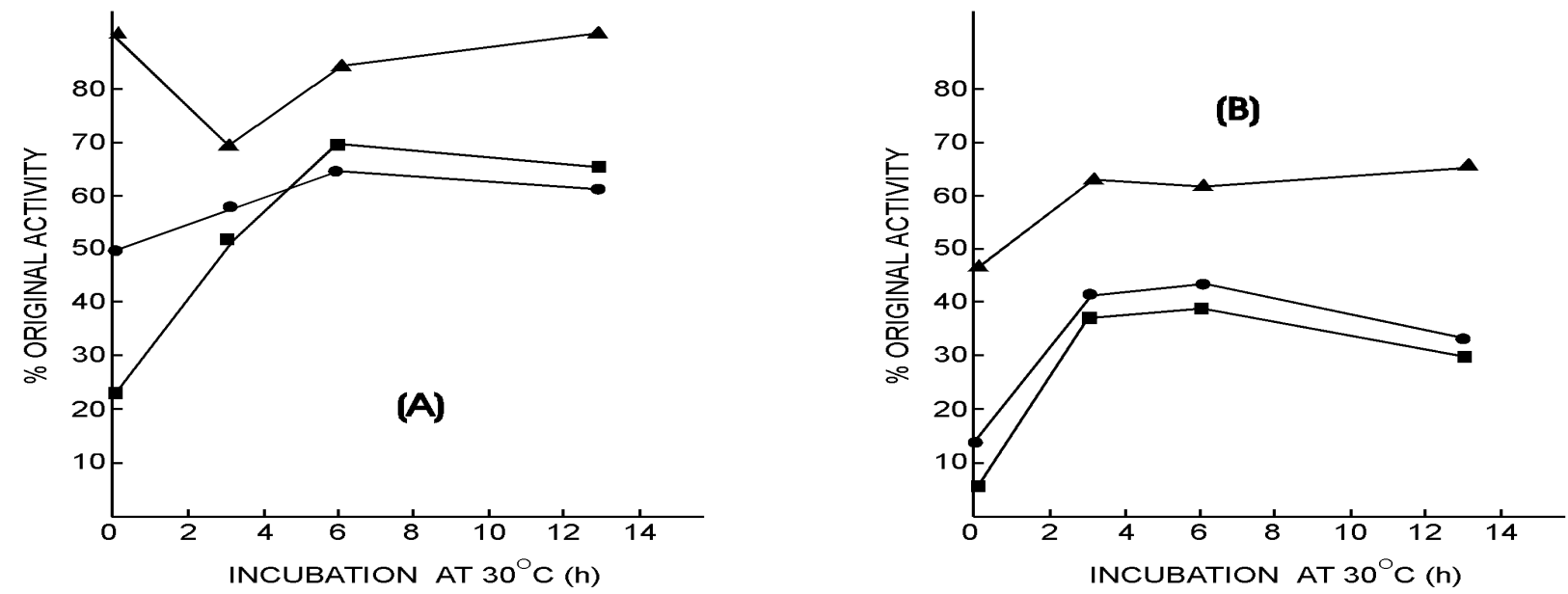

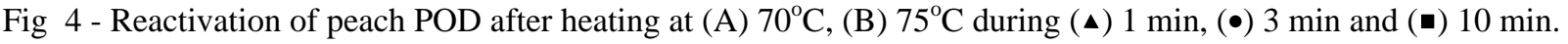

Although a low residual activity was detected after heating at $75^{\circ} \mathrm{C}$ for 3 and $10 \mathrm{~min}$, the enzyme regained 30 and $40 \%$ of its original activity; these recoveries were much higher compared to that determined after $1 \mathrm{~min}$ of heating. Halpin et al.,1989, while studying the major isoenzyme from green peas, observed a regain of activity of 15 to $30 \%$. Similarly, McLellan \& Robinson,1984, noted that the cabbage and Brussels sprout peroxidases heated at $75^{\circ} \mathrm{C}$ regained $16 \%$ of the original activity after incubation at $30^{\circ} \mathrm{C}$. In contrast to these results, Khan \& Robinson,1993a, when studying the heat regeneration of mango peroxidases in a crude extract, showed that soluble and ionicallybound enzymes did not reveal any substantial regain of activity, as also Clemente, 1996, noted an only little activity regeneration of orange juice isoperoxidases after partial heat inactivation. 


\section{ACKNOWLEDGEMENTS}

The authors would like to thank to Conselho Nacional de Desenvolvimento Científico e Tecnológico-CNPq and Agrícola Itamirim S.A.

\section{RESUMO}

A peroxidase de pessego foi purificada 28,9 vezes por cromatografia de DEAE-celulose, Sephadex G-100 e hidroxiapatite. A enzima purificada mostrou um único pico de atividade apresentando $\mathrm{pH}$ ótimo de 5,0 e temperatura de $40^{\circ} \mathrm{C}$. A energia de ativação para a reação foi $7,97 \mathrm{kcal} / \mathrm{mol}$. A enzima mostrou-se termolábil na faixa de 60 a $80{ }^{\circ} \mathrm{C}$, e com uma inativação rápida a $80{ }^{\circ} \mathrm{C}$. A eletroforese em gel de poliacrilamida do transcurso da inativação a $70{ }^{\circ} \mathrm{C}$ mostrou uma só banda de atividade. Diferentes tipos de açucares aumentaram a estabilidade térmica da atividade enzimática, na seguinte ordem: sacarose $>$ lactose $>$ glicose $>$ frutose. Medida da atividade residual mostrou um efeito estabilizante da sacarose a várias relações temperatura/concentração $(10$ a $40 \%, \mathrm{p} / \mathrm{p})$. A energia de ativação para inativação aumentou com aumento crescente da concentração de sacarose de 0-20\% (p/p). Após inativação a 70 ${ }^{\circ} \mathrm{C}$ e $75{ }^{\circ} \mathrm{C}$ a enzima foi capaz de ser reativada até $40 \%$ da atividade inicial quando armazenada a $30{ }^{\circ} \mathrm{C}$.

\section{REFERENCES}

Abeles, F.B. \& Biles, C.L. (1991) Characterization of peroxidase in lignifying peach fruit endocarp. Plant Physiology., 95, 269-273.

Arakawa, T. \& Timashef, S.N. (1982) Stability of protein structure by sugars. Biochemistry, 21, 6536-6544.

Bradbury, S.L. \& Jacoby, W.B. (1972.) Glycerol as an enzyme-stabilizing agent: Effects on aldeyde-dehydrogenase. Proc Natl. Acad. Sci. USA, 69, 2373.

Burnette, F.S.(1977) Peroxidase and its relation to food flavor and quality. A review. J. Food Sci., .4, 1-6.
Chang, B.S., Park, K.H \& Lund, D.B. (1988) Thermal inactivation kinetics of horseradish peroxidase. $J$. Food Sci., 53, 920-23.

Clemente, E. (1996) Isolamento, purificação e termoestabilidade da isoperoxidase do suco de laranja. Ciênc. Tecnol. Aliment., 16, 1-5.

Davis, B.J. (1964) Disk electrophoresis. II. Method and application to human serum protein. Annals New York Acad. Sci., 121, 404-27.

Frigon, R.P. \& Lee, J.C (1972) The stabilization of calf-brain microtubule by sucrose. Arch. Biochem. Bioph., 153, 587.

Gerisma, S.Y. (1968) Reversible denaturation of ribocuclease in aqueous solutions as influenced by polyhydric alchool and some other additives. $J$. Biol. Chem., 243, 957.

Gillikin, J.W. \& Graham, J.S. (1991) Purification and developmental analysis of the major anionic peroxidase from the seed coat of Glycine max. Plant Physiology, 96, 214-220.

Gorin, N. \& Heidema, F.T. (1976) Peroxidase activity in Golden Delicious apples as a possible parameter of ripening and senescence. J. Agric. Food Chem., 24, 200-01.

Haard, N.F. (1973) Upsurge of particulate peroxidase in ripening banana fruit. Phytochemistry, 12, 555-60.

Haard, N.F. (1977) Physiological roles of peroxidase in posharvest fruits and vegetables. In.: Ory, R.L. \& St.Angelo,A.J., eds. Enzymes in food and beverages processing. ACS; p-143.

Halpin, B., Pressey,R., Jen, J.J. \& Mody, N. (1989) Purification and characterization of peroxidase isoenzymes from green peas (Pisum sativum ). J. Food Sci., 54, 644-49.

Hammerschmidt, R., lamport, D.T.A., Muldoon, E.P. (1984) Cell wall hydroxyproline enhancement and lignin deposition as an early event in the resistance of cucumber to Cladosporium cucumerium. Physiol. Plant Pathol., 24, 43-47.

Hemeda, H.M. \& Klein, B. (1991) Inactivation and regeneration of peroxidase activity in vegetables extracts treated with antioxidants. J. Food Sci., 56, 68-72.

Khan, A.A. \& Robinson, D.S. (1993a) Purification of anionic peroxidase isoenzyme from mango (Mangifera indica L. var. Chaunsa). Food Chemistry, 46, 61-64.

Khan, A.A. \& Robinson, D.S. (1993b) The thermostability of purified mango isoperoxidases. Food Chemistry, 47, .53-59.

Lee, J.C. \& Timashef, S.N. (1981) The stabilization of proteins by sucrose. J. Biol. Chem., 256, 7193-201.

Lourenço, E.J. \& Neves, V.A. (1997) Peroxidase solúvel de pêssego: purificação parcial e propriedades. Ciênc. Tecnol. Aliment., 17, 42-48. 
Lowry, O.H., Rosebrough, N.J.; Farr, A.L. and Randall, R.J. (1951) Protein Measurement with the Phenol reagent. J. Biol. Chem., 193, 265-75.

Lu, A.T. \& Whitaker, J.R. (1974) Some factors affecting rates of heat inactivation and reactivation of horseradish peroxidase. J. Food. Sci., 39, 1173-77.

McLellan, J.M. \& Robinson, D.S. (1984) Heat stability of peroxidase from orange. Food Chemistry, 13, 139-47.

Miesle, T.J., Proctor, A., Lagrimini, L.M .(1991). Peroxidase activity isoenzymes, and tissues localization in developing highbush bluberry fruit. J. Amer. Soc. Hortic. Sci., 116, 827-30.

Neucere, N.J. \& St Angelo, A.J. (1985) Physicochemical properties of peanut protein in sucrose. Anal. Biochem., 47, 80-89.

Neves, V.A. \& Lourenço, E.J. (1985) . Extração e atividade da peroxidase e polifenoloxidase de batata-doce (Ipomoea batatas Lam.). Rev. Ciênc. Farmac., 7, 101-107.

Park, J.W. \& Lanier, T.C. (1987) Combined effects of phosphates and sugars or polyol on protein stabilization of fish myofibrils. J. Food Sci., 52, 1509-13.

Rhothan, C. \& Nicolas, J. (1989) Changes in acidic and basic peroxidase activities during tomato fruit ripening. Hortic. Sci., 24, 340-42.

Schmidt, K. \& Vamos-Vigyazo, L. (1981) Inactivation of a soluble peroxidase from acetone
Sessa, D.J. \& Anderson, R.L. (1981) Soybean peroxidases: purification and some properties. $J$. Agric. Food Chem., 29, 960-65.

Silva, E., Lourenco, E.J. \& Neves, V.A. (1990) Soluble and bound peroxidases from papaya fruit. Phytochemistry, 29, 1051-56.

Smith, J.A. \& Hammerschmidt, R. (1988) Comparative study of acid peroxidases associated with induced resistance in cucumber muskmelon and watermelon. Physiol. Molec. Plant Pathol., 33, 255-61.

Soda, I.; Hasegawwa, T.; Suzuki, T. \& Ogura, N. (1991) Purification and some properties of peroxidase from kiwifruit. Agric. Biol. Chem., 55, 1677-78.

Tamura, Y. \& Morita, Y. (1975) Thermal denaturation and regeneration of japanese-radish peroxidase. $J$. Biochem., 78, 561-71.

Vàmos-Vigyàzo, L. (1981) Polyphenoloxidase and peroxidase in fruits and vegetables. C.R.C.-Crit. Rev. Food Sci. Nutr., 15, 49-127.

Yoovidhya, T., Combes, D. \& Monsan, P. (1986) Kinetic and stability studies of rulactine a proteolytic enzyme from Micrococcus caseolitycus. Biotech. Letters, 8, 333-40.

Received: November 20, 1997; Revised: May 20, 1998; Accepted: August 06, 1998. 
